\title{
COMO FALAR DOS LIVROS QUE NÃO LEMOS? \\ UMA DEFESA DA NÃO LEITURA
}

Fernanda Müller

Doutoranda em Teoria da Literatura - UFSC

Cínico e tranqüilamente hipócrita ou honesto, corajoso e revolucionário? Pierre Bayard oferece uma gama de nomes sob os quais poderia ser classificado ao aceitar a incumbência de desmistificar o mundo das letras. Afinal de contas, quais adjetivos empregar para descrever o professor, psicanalista e escritor francês cujo livro é destinado a incentivar que se fale de quaisquer obras, mesmo as jamais lidas? Combatendo o clichê do "não julgue um livro pela capa", o autor sugere que em alguns casos até esse contato mais imediato poderia bastar, desafiando o leitor a repensar suas abordagens de leitura. Deparamo-nos com a questão: seria a não leitura uma prática de leitura válida ou, melhor dizendo, desejável?

Nascido em um meio onde se lia pouco, Pierre Bayard revela que foi lançado pela profissão em um universo da mais alta erudição. Seu livro é dedicado, então, a assumir-se publicamente como um não leitor, propondo que se deixe de encarar a leitura 
como obrigação sacra e o conhecimento do cânone como dever moral. Revertendo o quadro inicial, o autor afirma que hipócrita é o sistema impositivo de obrigações e proibições, responsável pelo fingimento geral sobre os livros supostamente lidos. Lado a lado com o dinheiro e a sexualidade, a leitura estaria, pois, entre os domínios da vida privada em que as informações são as mais inseguras possíveis.

Sua obra Comment parler des livres que l'on n'a pas lus? (Como falar dos livros que não lemos? Objetiva, 2007) pode ser considerada uma pequena teoria da leitura, ou melhor, da não leitura, elaborada seguindo três eixos principais. A primeira parte é dedicada às "maneiras de não ler": os livros que não conhecemos, os que folheamos, os de que ouvimos falar e mesmo os que esquecemos, todas formas válidas de abordagem que não equivalem a um livro fechado, mas a degraus para galgar a categoria da não leitura. Neste capítulo o leitor é apresentado a tipos como o bibliotecário do romance $O$ homem sem qualidades, de Musil, que diante do número infinito de publicações opta radicalmente por não ler nenhuma delas, mas dominar os catálogos que as relacionam. Também é exposto o procedimento utilizado por Paul Valéry para dispensar tanto autor quanto texto ao compor uma crítica; sem falarmos no exemplo extremo de Montaigne que esquecia do conteúdo de um livro lido, como também se chegara a ler ou não tal livro e, pior, não se lembrava sequer de textos que ele mesmo escrevera.

A segunda parte da obra coloca em evidência saias justas discursivas e os meios de se sair bem delas, como é o caso de um professor em sala de aula que fala em seu dia-a-dia de livros não lidos; diante de um avaliador que deseja testar os conhecimentos de alguém que não leu o texto; perante o ser amado que busca identificação através de uma obra que supostamente ambos leram; e, mais delicado ainda, frente ao autor de um livro que busca nossa opinião. Unindo as duas partes, encerra seu texto em um capítulo que oferece conselhos simples "reunidos ao longo de uma vida de não leitor", tais quais não ter vergonha de se expressar, impor as próprias idéias, inventar os livros aproveitando-se da memória fragmentada do interlocutor ou desviar com criatividade do assunto principal para falar de si. 
Coerente com a cartilha de não leitor, o próprio ensaio de Bayard é estruturado a partir das propostas desenvolvidas no livro. Um exemplo é o fato de buscar convencer angariando a força de cada capítulo junto a uma personagem ou a uma personalidade que igualmente utilize a não leitura. Oscar Wilde é o ícone por excelência desse procedimento ao proferir as palavras escolhidas como epígrafe da obra "jamais leio um livro do qual tenha que escrever a crítica; nos deixamos influenciar muito facilmente". Para o escritor inglês a duração correta da leitura de um livro seria de seis minutos, caso contrário corre-se o risco de esquecer que o texto a ser elaborado seria antes um pretexto para se escrever a própria auto-biografia, esta sim motivação adequada para todo crítico que aceita o dever de ser antes de tudo fiel a si mesmo.

Além disso, é interessante notar que precedendo os textos há uma "tabela de abreviações" utilizadas para pontuar em notas de rodapé a familiaridade de Bayard com o livro citado (LD - livro desconhecido; LF - livro folheado; LO - livro de que ouviu falar; e LE - livro esquecido) e sua opinião sobre ele, proferida independentemente do grau de contato com o exemplar (++ opinião muito positiva; + opinião positiva; opinião negativa; e -- opinião muito negativa). Seguindo rigorosamente tal preceito, Bayard ironicamente classifica o livro escrito por ele mesmo, a obra Qui a tué Roger Ackroyd?, como LE+, ou seja, livro esquecido sobre o qual teria opinião positiva. Esse sistema de abreviaturas, aliado à estrutura enxuta, ao tom ensaístico e às pequenas sínteses que antecedem cada texto facilitam o devaneio do leitor pela obra. Para não falar na sua não leitura.

A grande contribuição de Bayard é a de revelar os bastidores do texto, expondo o procedimento de muitos professores (entre os quais se inclui), críticos, pensadores e editores que, independentemente de não terem lido, não se eximem de comentar o não lido. Ora, quem nunca se sentiu coagido diante de um interlocutor qualquer por um livro não lido; jamais ouviu uma argüição vaga, abstrata e em todo caso sobre outra coisa que não o texto em questão; ou descobriu que o livro lido anteriormente não correspondia àquele gravado na memória, pois que atire a primeira pedra. Longe de os culpar, o escritor chama atenção para a necessária libertação, revelando como a prática da não leitura não é a supressão da leitura, mas um procedimento que seria igualmente rico para quem nele se aventurar. Abandonando a idéia da leitura como o correr de olhos da primeira à última linha do texto, quer seja, um procedimento que visa à integralidade do 
conteúdo, Bayard aponta a importância do leitor situar o texto tanto dentro de uma biblioteca universal, quanto no horizonte de seus capítulos. Incorporando informações obtidas em diversas fontes, a não leitura é oferecida como uma alternativa de leitura que não substitui a linear, mas evidencia como esta não é a única forma de contato com um texto.

Pregando o fim da mentira e da culpa, bem como o ensino dessa nova abordagem como missão, Bayard redime os leitores - e sobretudo os não leitores - do peso que lhes é imposto. Aos céticos de plantão, resta o lembrete de que a produção humana é grande demais para se julgar possível abarcar parcela significativa do conhecimento. $\mathrm{O}$ que não significa cruzar os braços perante o livro fechado, mas ter a consciência de que o domínio de uma obra "lida" é um conhecimento frágil e fugidio. Para quem insistir na classificação "livro lido" versus "livro não lido" resta a maliciosa pergunta: como agrupar, então, os livros lidos e esquecidos?

\section{Referências}

BAYARD, Pierre. Como falar dos livros que não lemos? Trad. Rejane Janowitzer. Rio de Janeiro: Objetiva, 2007. 